\title{
5.2 デジタルフォトグラメトリックワークステーション
}

\author{
棚 橋 有三*
}

Yuzo TANAHASHI

\section{はじめに}

機械, 光学系を主とした A 8 に代表されるアナログ 四化機から，ここ10年来, 導入されてきた解析図化機 は，その主たる部分をコンピューターに代替させ，写 真測量に於ける図化機の応用範囲, 又, 操作性を高め てまいりました。ここ数年, ランドサット，スポット に代表される衛星画像をりモートセンシング応用のみ でなく，写真測量への対応も検討され始めました。

パーソナルコンピューター及び高性能ワークステー ションによる画像処理技術もコンピューターの性能と 比例して多大な進歩を示しており，スキャナー等の出 現により，写真として従来扱われてきた媒体をデジ夕 ルデーターとして扱う事も可能になりました。この様 な技術革新は, 写真測量に於いて, 今まで写真として 报われてきた画像をデジタル画像として扱う事を可能 とし, 写真測量の処理方法を革新的に変える装置の実 現性を生む事となりました。

ここに紹介するデジタルフォトグラメトリックワー クステーションは, 写真測量に於けるデジタル画像処 理に対応すべく開発された装置です。

\section{1. 概 要}

デジタルフォトグラメトリックワークステーション (DPW), (写真 1) は, 以下の部分から構成されます。

(a) Sun Sparc Station 及び各種周辺装置

(b)画像及び図形処理ハードウェアー

(c)高解像カラーステレオ画像表示装置

(d)画像及び図形を対話型で操作する為のカラーモニ 夕-

*ライカ(株)

「写真測量とリモートセンシング」Vol. 32, No. 6, 1993

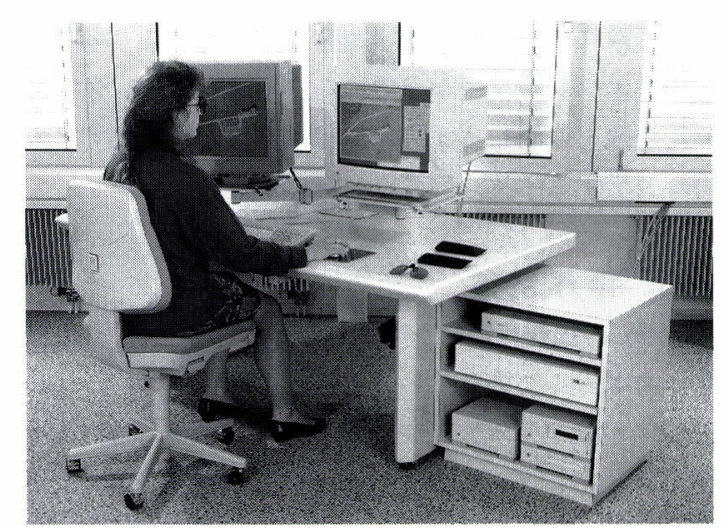

(写真 1)

(e) Sun Sparc Station システムソフトウェアー

(f)アプリケーションソフトウェアー：モデル標定,

DTM 自動生成, デジタルマッピング, その他 以下にそれぞれのハードウェアー，ソフトウェアー について説明を致します。

\section{2.ハードウェアー}

\section{1 ホストコンピューター及び周辺装置}

DPW のホストコンピューターは, SUN の最新モデ ルが採用されています。(SPARC10)

システムには，ハードディスク及びデーターバック アップ用のデジタルデーターテープ装置が必需となり ます。メモリーは最小 $32 \mathrm{MB}$ 必要です。

\section{2 画像及び図形処理装置}

DPW には, 画像/図形処理及びステレオ表示装置 が含まれます。この装置により，デジタル画像をリア ルタイムで表示するとともに, 測定が可能となります。 ステレオ画像プロセッサーにより，生成されるメス マークがステレオモデル内に表示されます。ソフト ウェアーにより，オペレーターは，メスマークを三次 元モデル内を移動し, 測地座標による計測を行う事が 
出来ます。

\section{3 ステレオ表示}

DPW は，ステレオデジタル画像の観測に受動型の 表示を使用しています。標準型の高解像カラーモニ ターのスクリーン前面に同サイズの着脱式の液晶 シャッターが取り付けられます。左，右の画像は，60 $\mathrm{Hz}$ の周期で, 時計回り, 反時計回りに偏光され, 交互 に表示されます。普通のメガネと同じサイズの偏光メ ガネをオペレーターが装着する事により，左，右それ ぞれの像を観測します。単画像表示及び左，右別々に 同時表示する手法も用意されています。

\section{4 操 作 制 御}

$\mathrm{DPW}$ の操作は, キーボード, 3 ボタンマウス, ト ラックポールにより行います。

マウスは，実体モデル内でのメスマークの $\mathrm{X} ・ \mathrm{Y}$ 動 作及びソフトウェアーメニュー選択に使用します。卜 ラックボールは，実体モデル内でのメスマークのZ動 作及び X・Y 動作にそれぞれ使用する事が出来ます。 別途，一般的な解析図化機と同じ，X·Y ハンドル， $Z$ 用の足盤が用意されています。

\section{3. ソフトゥェアー}

\section{1 概 要}

システムソフトウェアーは, AT\&T System V UNIX 及びバークレイ版 UNIX と互換性を持つ, SUN O.S.を使用します。ユーザーがC 言語で作成す るプログラム開発用の C コンパイラーも用意されてい ます。UNIX の特徵のマルチユーザー, マルチタスク 環境により，資源の効率の良い活用が可能です。

DPW で用意されているアプリケーションソフト ウェアーは，C 言語で作成されています。ソフトウェ アーとして, 画像, データー入力, モデル標定, DTM 生成, デジタルマッピング, デジタルオルソフォト作 成, 三次元モデル表示, 画像, データー出力等があり ます。

使用できる画像は, 航空写真, 地上写真, パノラマ 写真, SPOT, LANDSAT 又, 各種座標系をサポート しています。

\section{2 画像表示機能}

DPW は，3つの画像表示モード：ステレオ又は三 次元表示；モノ又は単写真表示；左，右スプリット表 示があります。画像機能として回転, リセンター, ズー ム, コントラスト及び輝度調整, カラーにより図形スー パーインポーズ等が用意されています。

\section{3 内 部 標 定}

スキャニングされた画像の内部標定を行うプログラ ムです。一般的な手順と同じで，画像に写し込まれて いる指標を測定し, ピクセル座標と写真座標の変換計 数を定義します。

指標測定時は，入力されている各指標規準值に沿っ て，既略の位置へ自動走行します。

測定は，マニュアル，自動（画像相関による）によ る手順があります。

(DSW100スキャニングワークステーションでス キャニングされた画像を扱う場合は, 内部標定は, 自 動処理となります。)

\section{4 空中三角測量（1～N 画像の外部標定）}

外部標定ソフトウェアーは, 最小二乗バンドル法を 使用し, 航空写真, パノラマ写真, SPOT, LANDSAT, 地上写真を 1 100画像処理できるソフトウェアーと なっています。

前述の画像を組み合わせての処理も可能です。標定 は, 相互, 絶対に分けて実行が可能です。基本パッケー ジ内で適用できる座標系は, UTM, Geographic, 平面 直交座標系があります。その他, 数種の適用できる座 標系も別途用意されています。標定点の測定に際して は, 種々の機能が用意されており, 測定点への自動走 行, 多重観測, 測定点の固定, 測定座標の標示, 測定 済みの点のシンボル表示等があります。

記．他のシステムでの空中三角により，外部定位が 求められている場合は, その值をそのまま標定に適用 できます。

\section{5 偏位修正/画像の準備}

偏位修正/画像の準備のソフトウェアーは, 入力画像 の前処理及びエピポラレイに沿った画像の再配列を自 動的に行います。エピポラレイに沿った画像の再配列 を行う事により, 後処理での自動画像相関処理が飛躍 的にスピード化されます。又，オペレーターによる実 
体観測の為にもこの画像配列は必要となり，この処理 をしない場合は，画像は大変見にくいものとなります。 画像再配列処理は, デジタル画像に加之, 標定要素 が必要となります。この要素は, 内部標定, 外部標定 から得られる各要素となります。再配列処理は, 自動 的に行われる為, オペレーターの介在は必要ありませ ん。再配列処理により, 画像の X 軸は, 左, 右の主点 位置を結ぶ軸に平行となります。又，標定結果から得 られた回転要素から, その成分も除去されます。処理 結果として, データーファイル, 画像ファイルとして, スレテオモデル分が内部フォーマットで出力されま す。偏位修正処理は，厳密な解析法により実行されま す。

前述したステレオ画像の偏位修正に加え, 画像全体, 又は, 1 部の画像の回転が左，右の独立して，別々に 行う事ができます。又，画像準備のソフトウェアーの 1 部として, 間引きした画像を作成する事が出来ます。 これは，2，4，8，16，32：1に解像度を間引きし た画像を作成し，ファイルに登録をします。

\section{6 自動 DTM（数値地形）生成}

DTM (数值地形) 生成の為の自動標高測定は, DPW の代表的な機能です。

画像データーは, 前述した偏位修正処理により, 用 意されます。オペレーターは，自動 DTM プログラム を実行し，必要となるパラメーター，測定範囲の指定， 点の間隔等を設定し，画像相関によるDTM 計算処理 をスタートさせます。指定範囲全体の計算が終了する まで，全て自動処理となります。処理スピードは，地 形の形態，画像のテクスチャー，処理パラメーターに より変わりますが，1秒当たり，5１00点となります。 DTM は, Hierarchical Relaxation Correlation (HRC) アルゴリズムを使用し，自動的に生成されま す。

この手法は, 最終的な DTM が生成される迄, 段階 的に低解像の画像から順番にオリジナル画像のピクセ ル単位の相関までを処理する手順を取ります。

HRC は，完全な自動処理です。計算処理に当たり， 使用画像の品質, 地形の形態により適用パラメーター セットを組み合わせた計算戦略ファイルが用意されて おり，このファイルを組み合わせる事により，計算処 理回数も変わり, 複雑になりがちな相関処理がわかり やすく実行できる様になっています。
計算結果は，各点の標高值とその相関度を示す指数 （FOM : Figure of Merit）が出力されます。自動処理 の過程に於いて, FOM が低い, 画像相関が出来なかっ た点が出てきた場合は, 隣接する点からの補間により 標高が決定されます。

この様な点は, オペレーターにより, 三次元表示さ れた後に検証され，必要であれば修正をします。修正 の為に, 数種の対話型の編集プログラムが用意されて います。

内容については，後述致します。

一般的な地形, 実体観測で表面が観測できる部分の 計測では，80\%〜95\%の値が修正の必要のない結果と して扱えるはずです。X視差の測定精度は，0.2〜1.0 ピクセル, B/H 比が0.6の場合, 標高の測定精度はピク セルサイズを測地に変換した值と同じとなります。

\subsection{DTM 表示}

DTMの自動作成の結果は，ステレオ画像に重ね合 わせて, 三次元表示することが出来ます。この表示方 法としては，断面，等高線，独標点，メッシュがあり ます。表示する場合, 標高値, 又は, 相関度の指数に より, 色分けして表示する事が出来ます。DTM は, 図 形のみを平面, 斜め, 透視困として任意の視点, 縮尺, $Z$ 比を指定し，表示させることも出来ます。

\subsection{DTM の対話型の編集}

自動的に生成された DTM を修正する為に，対話型 の編集プログラムが用意されています。前述した表示 方法により，計算した結果は，ステレオ画像に重ね合 わせ表示できる為, 誤った点は, 簡単に発見する事が 出来ます。従って, 編集プログラムによりこれらの間 違って計算された点の再測を行います。オペレーター は, 個々の点を色々なツールを使用して測定, 修正す ることが出来ます。これらのツールは，より簡単に， 更に, 迅速に修正作業を行う為に用意されたものです。 ツールとして,

(a)連続的に移動しながらの修正（断面測定）

(b)停止しながらの修正（1 点毎の測定）

(c)隣接する点からの補間

(e) $3 \times 3,5 \times 5$ の点によりスムージング

(f)ブレークライン等の地形形態定義

(a)，(b)のツールは，対話型の処理ですが，他のツー ルはバックグランドで実行できるバッチ的な処理で 
す。全てのツールは，メニュー形式からの選択による 実行となります。

\section{9 オルソフォト}

デジタルオルソフォトの作成及び出力も DPW の代 表的な機能と言えます。

オルソフォト作成に必要な入力は, DTM データー, 画像データー, 外部標定要素, オルソフォト作成範囲 座標，そして出力する場合のピクセルサイズ (Ground Sample Distance) となります。

出力は正射変換された画像ファイルとなります。

正射変換処理は, DTM の標高値と, 外部標定からの 要素を使用し，ピクセル毎の標高值を補間すると同時 に必要な幾何学的な変換を行い，隣接ピクセルからピ クセル毎の濃度を決定します。

\subsection{0 デジタルマッピング}

表示されるステレオ画像を観測しながら，一般的な マッピングを行うプログラムが用意されています。収 録されるデーターは，三次元でリアルタイムで画像に スーパーインポーズされる為, 効率の良い作業が行え ます。又，等高線の処理は，自動作成された DTM を 等高線として表示し, 修正が必要な部分のみを収録す るだけとなります。

\subsection{1 出 力}

DPW に作成されたものは, 磁気テープ等のメディ ア, インクジェットプリンター, フィルムレコーダー, プロッター等, 種々の出力機へ出力する事が出来ます。 又, 収録された数值情報は, DXF を代表とする数種の フォーマットへ変換出力する事が可能です。

\section{4. 精度}

DPW に於ける精度は, 適用する数学式, 画像計算の 精度, ピクセルサイズに関連します。処理が全てデジ タルで行われる為, 光学, 機械構造から派生する系統 的な誤差は，全て無視する事が出来ます。全ての計算
は，倍精度で行われ，メスマークの位置は，サブピク セルの精度で決定されます。

通常, 画像の測定精度は, 画像の品質及びオペレー ターの熟練度によりますが, $0.5 \sim 1$ ピクセルの範囲と 言えます。この值は, 短い測定の範囲で解像度, 精度 としてピクセル当たりの0.6〜1.1に対応すると言えま す。長い測定の範囲では，センサー及びスキャナーの 誤差により，絶対的な精度は悪くなります。ほとんど の画像, 良品質のスキャナ一の精度は，ピクセルのサ イズと同量であると推察できます。

ドラムスキャナーの場合は, フィルムの平面性, ド ラムの回転時の誤差により，附加的な誤差を生じると 言えます。

自動測定及びマニュアル測定で，画像のズーム倍率 が $2 \sim 4$ 倍の場合, 0.3 ピクセル内の精度が得られると 思いますが，スキャナーを使用した画像の場合は，ス キャナ一自身の系統的な誤差がこの值より大きくなる のであてにはなりません。

測地座標に於ける絶対的な精度は, 主として，ワー クステーション内で制御できないファクターによるも のとなります。これは, 基準点座標の精度, 画像スキャ ニングの品質, カメラキャリブレーション精度, そし てフィルムの扱い等となります。これらのファクター の為，代表的な数值だけを明示することとします。

SPOT 画像の場合, 精度は $6 \sim 25 \mathrm{~m}$ の範囲。標高值 は, 画像の幾何学的な配置によりますが, $\mathrm{B} / \mathrm{H}$ が 1 近 くとして，6〜12m の範囲。

\section{5. ま ぬ}

デジタルフォトグラメトリーは, ワークステーショ ンの技術進歩に比例して，コストパフォーマンスの優 れたものが今後紹介されていくと思います。ソフト ウェアーによる自動化の可能性を無限に秘めていると 思いますが，日常的な作業に使用される様になるには， 特徵的なアプリケーションが実際の需要として出てく る必要があると思います。 